\title{
STUDENTS' RESPONSES TOWARD THINK TALK WRITE STRATEGY IN TEACHING WRITING
}

\author{
Ika Yulia Anggraeni ${ }^{1}$, Yanuarti Apsari ${ }^{2}$ \\ 1,2 IKIP Siliwangi \\ ${ }^{1}$ ikayulia11@ student.ikipsiliwangi, ${ }^{2}$ yanuar.apsari1@gmail.com
}

\begin{abstract}
Writing skill is one of the skills that is difficult to learn because we have to know the correct sentence composition and also what we hear must be in accordance with what we write and therefore this skill is very important to learn. The objective of the research is to identify the sudents' responses toward think talk write (TTW) strategy in teacihng writing skill. The research used descriptive qualitative design. The respondents of this research were eighth grade students of SMP Pasundan 1 Cimahi. The instrument of this research was questionnaire. The result of data analysis shows that students gave positive responses toward TTW strategy. The respondents agree that TTW strategy can increase students' motivation, TTW Strategy can help students in improving their writing skill and TTW strategy can make teaching and learning process interesting.
\end{abstract}

Keywords: Writing, Think Talk Write (TTW) Strategy, Student's Responses

\section{INTRODUCTION}

Writing skill is one of the skills that is difficult to learn because we have to know the correct sentence composition and also what we hear must be in accordance with what we write and therefore this skill is very important to learn. According to Harmer (2004) as cited in (Suminar \& Putri, 2018) Writing skill is often needed to measure knowledge in most exams, whether they are testing in foreign language abilities or other skills. students' writing skills can be developed by knowing the correct grammar, content, organization, and vocabulary, cont. in addition, students must be able to develop ideas for sharing information, to provide arguments in the form of sentences or short paragraphs. One of the problems in teaching writing is that students cannot write a text correctly because there are still considerations of several aspects in writing. aspects of writing including grammar, generic structure and sentence structure. Sometimes students find it difficult to determine the correct grammar and sentence structure in each type of text. writing one of the activities in teaching writing is descriptive text.

There are several types of text writing in junior high school. in each text there are differences in social functions, general structure and also language features. The students are already introduced one of the several text writing such as descriptive text. According to Rachmat (2009:14) as cited in (Wiyak \& Ansori, 2017), descriptive text is used in all forms of writing to create a vivid impression of a person, place, object or event e.g. to describe a special place and explain why it is special, to describe the most important person in your life, or to describe the animal's habitat in your report. The meaning of text that has a social function to describing a characteristic of a person, animal, object, and place. However, there are some common problems encountered by students in writing descriptive text The students are confused to start writing descriptive text, and how to express their creativity in writing text, furthermore, they have difficulties in arranging the generic structure, social function and language features of the paragraph of descriptive text. 
To solve the problems and improve the students writing abilities teachers needs to use an appropriate strategy which make the students interest and enthusiastic the writer thinks that the students' learning ability and motivation depends upon the effectiveness of the teachers" teaching strategy. Because most students still find conventional teaching in the learning process of English is boring. One of strategy that will overcome students" writing problem is ThinkTalk-Write (T-T-W) strategy.

The think-talk-write strategy is a cooperative learning mode to make teaching and learning process more manageable. By using this strategy, the students are allowed to interact with their groups and to create active and effective leaning. According to Huinker and Laughin (1996) as cited in (Zulkarnaini, 2011) The Think-Talk-Write strategy is students' can builds in time for thought, reflection and for the organization of ideas and the testing of those ideas before students are expected to write. the flow of communication in learning strategies is very influential on teaching and learning activities in later classes of students involved in thinking or reflecting on ideas and information that they get through discussing with friends of one group and expressing ideas to each other can then pour into the writing based on their ideas.

Based on the explanation above, think talk write strategy is a teaching strategy that can develop ideas and information that they know then compare these ideas through discussions with peers as a group, so they will get more different ideas based on individual thinking and that will make students become confident to use their own languagein writing activities because they believe that their ideas are good.

\section{The Advantages of Think-Talk-Write Strategy}

Huinker \& Laughlin (1996: 82) as cited in (Subkhan, 2016) have stated that TTW has some advantages in learning process of writing;

1. Allow students to interact and collaborate to talk about his research or their little notes with other members of his group

2. Students engage directly in learning so motivated to learn

3. This model centered on students, e.g. provide an opportunity in teacher and students served as mediators of learning environment. The teacher becomes the student participation rate monitoring and especially in the discussion. This means that this strategy can give advantages for students to create diverse ideas from discussion one another in writing.

4.

\section{The Procedure of Think-Talk-Write in Descriptive paragraph}

According to Silver and Smith (1996:21) as cited in (Tambunan, 2011) there are series that should be follow insetting up Think-Talk-Write Strategy.

1. The teachers devides classroom into several groups. In group consist of 4-6students.

2. Teacher explain about Descriptive paragraph.(Generic structure andLanguages Features).

3. The teacher divides the picture relating to students' daily environment. Example : Picture of Lake Toba

4. Students describe the picture in their imagination and make notesindividually small (think). Each student in group describe the picture of LakeToba with individually, what they think about lake Toba, This activity isintended for students to distinguish or bring together the ideas contained inthe readings for later translated into the language itself. 
5. Students discuss with friends in groups to discuss the contents of the note theymade (talk). In this activity, Students discuss the results of a collection ofideas that they make in individually in thenote about what they know of Lake Toba.

Example of a small note from a student in group: Lake Toba has cool water and cool air

6. After students collect and discuss the results of any of their ideas. Students concluded the results of their ideas into a paragraph description and then theydetermine where the generic structure of the paragraph that they make (write).

7. The final activity the Students write down the paragraph descriptive that theymake in a paper.

\section{METHOD}

The method of this research was descriptive qualitative method to identify students' responses in teaching writing descriptive text. This research was conducted from one of Junior High School in Cimahi. Population of this research was eighth grade students, the participants were 28 students with different character in writing skill. To identify students responses, the researcher collect the data used questionnaire. According to Kothari (2004), questionnaire is concerned, it can either be structured or unstructured questionnaire. Structured questionnaires are those questionnaires in which there are definite, concrete and pre-determined questions. The questions are presented with exactly the same wording and in the same order to all respondentsThe questionnaire was contained both close and opend ended question.

\section{RESULTS AND DISCUSSION}

\section{Results}

In this section, the researcher discussed the result of the research which gained through questionnaire. In order to find out the teaching writing on descriptive text with think talk write strategy, the researcher observed the teaching process of the VIII C class. There were 28 students in VIII C class, 7 students were absent. The researcher classified the students' answer of questionnaire form to know the exact number of the student's answer in the questionnaire sheets. From these data, the researcher knew the students' opinion

The questionnaire consist of 10 questions. It was used to find the students' interest, difficulties, understandings, and motivations in learning process. Close questions The description of the questionnaire explained in the table as follow:

Table 1 Result of Questionnaire Data Analysis

\begin{tabular}{llll}
\hline \multirow{2}{*}{ No } & Pertanyaan & \multicolumn{2}{l}{ Pilihan Jawaban } \\
\cline { 3 - 4 } & Ya & Tidak \\
\hline 1 & Apakah pembelajaran menggunakan strategi TTW (Think & 26 & 2 \\
& $\begin{array}{l}\text { Talk Write) yang telah dilaksanakan membuat anda } \\
\text { memiliki kemauan yang tinggi untuk mengikuti pelajaran? }\end{array}$ & & $(92,85 \%)$ \\
\hline 2 & $\begin{array}{l}\text { Apakah kamu lebih merasa percaya diri untuk } \\
\text { menyampaikan pendapat dalam proses pembelajaran }\end{array}$ & & \\
& $\begin{array}{l}\text { menggunakan strategi TTW (Think Talk Write)? } \\
\text { Apakah pembelajaran menggunakan strategi TTW (Think }\end{array}$ & & \\
\hline 3 & 28 (100\%) & - \\
\hline
\end{tabular}




\begin{tabular}{|c|c|c|c|}
\hline & $\begin{array}{l}\text { mengembangkan ide atau gagasan dalam menulis teks } \\
\text { deskriptif? }\end{array}$ & & \\
\hline 4 & $\begin{array}{l}\text { Apakah pembelajaran menggunakan strategi TTW (Think } \\
\text { Talk Write) yang telah diterapkan membantu kamu } \\
\text { mengetahui kosa kata baru dalam bahasa Inggris? }\end{array}$ & $28(100 \%)$ & \\
\hline 5 & $\begin{array}{l}\text { Apakah belajar descriptive text menggunakan strategi } \\
\text { TTW (Think Talk Write) membantu kamu memahami } \\
\text { bagaimana menyusun kalimat atau grammar? }\end{array}$ & $\begin{array}{l}26 \\
(92,85 \%)\end{array}$ & $\begin{array}{l}2 \\
(7,15 \%)\end{array}$ \\
\hline 6 & $\begin{array}{l}\text { Apakah pembelajaran menggunakan strategi TTW (Think } \\
\text { Talk Write) yang telah diterapkan membantu kamu } \\
\text { mengetaui cara membuat teks deskriptif yang benar? }\end{array}$ & $\begin{array}{l}27 \\
(96,42 \%)\end{array}$ & $\begin{array}{l}1 \\
(3,58 \%)\end{array}$ \\
\hline 7 & $\begin{array}{l}\text { Apakah kamu mengalami kesulitan dalam menulis teks } \\
\text { deskriptif dengan menggunakan strategi TTW (Think Talk } \\
\text { Write)? }\end{array}$ & $\begin{array}{l}5 \\
(17,85 \%)\end{array}$ & $\begin{array}{l}23 \\
(82,15 \%)\end{array}$ \\
\hline 8 & $\begin{array}{l}\text { Apakah kamu memahami tahapan pembelajaran } \\
\text { menggunakan strategi TTW (Think Talk Write) yang telah } \\
\text { diterapkan? }\end{array}$ & $\begin{array}{l}24 \\
(85,71 \%)\end{array}$ & $\begin{array}{l}4 \\
(14,29 \%)\end{array}$ \\
\hline 9 & $\begin{array}{l}\text { Apakah pembelajaran teks deskriptif } \\
\text { strategi TTW (Think Talk Write) } \\
\text { menyenangkanakan dan tidak membosankan? }\end{array}$ & $\begin{array}{l}26 \\
(92,85 \%)\end{array}$ & $\begin{array}{l}2 \\
(7,15 \%)\end{array}$ \\
\hline 10 & $\begin{array}{l}\text { Apakah pembelajaran menggunakan strategi TTW (Think } \\
\text { Talk Write) dapat membuat proses pembelajaran dikelas } \\
\text { menjadi kondusif? }\end{array}$ & $\begin{array}{l}18 \\
(64,28 \%)\end{array}$ & $\begin{array}{l}10 \\
(35,72 \%)\end{array}$ \\
\hline
\end{tabular}

\section{Discussion}

The result of several questions above are interpreted into:

The result of first in question no. 1 indicates that $92,85 \%$ most of students have a high willingness to participate in classroom learning activities using the think talk write strategy because it can improve writing ability. In addition, the students also said that teaching writing with a think talk write strategy made it easier for students to develop their ideas. The others is the lowest quantity $(7,15 \%)$ was disagree that learning descriptive text using think talk write are can make students have a high willingness to participate classroom learning activities. Some of them said do not understand about descriptive text specifically with think talk write strategy.

Question no. 2 shows that $75 \%$ most of students stated that the learning process using the think talk write strategy can make students more confident in expressing their opinions. because by using this strategy students can share opinions or information they have with members of a group. The others is the lowest quantity (15\%) was disagree that the learning process using the think talk write strategy can make students more confident in expressing their opinions.

Question no.3 shows that all of the students (100\%) say that learning descriptive texts using the think talk write strategy can help students develop ideas or information in writing descriptive texts. that way students can describe a place based on the pictures they observe. 
Question no.4 shows that all of the students say $(100 \%)$ that learning descriptive texts using the think talk write strategy can help students to know the new vocabulary in English so that students can add new vocabulary, especially in descriptive text.

Question no.5 shows that most of the students say $(92,85 \%)$ that learning descriptive text using think talk write strategy can improve students' knowledge, and understanding of arrangement sentences or grammar. By understanding grammar, students can make descriptive text in a structured manner and in accordance with the language features used in the descriptive text.

Question no. 6 shows that most of students say $(96,42 \%)$ that learning by using think talk write strategy can help students to know how to make descriptive text correctly, and know the composition of the generic structure and language features used in the descriptive text.

Although students enjoy learning descriptive text, in question no.7 indicates that $(17,85 \%)$ of the students say that have some problems in writing descriptive text using think talk write strategy. They said that have some difficulties to construct language features and generic structures. The others who is in the bigger quantity $(82,15 \%)$ said that they have no problems and difficulties in writing descriptive text.

Question no.8 shows that most of the students $(85,71 \%)$ agree that they understand the steps of learning descriptive text using the TTW (think talk write) strategy. The others who is in the lowest quantity $(14,29 \%)$ say that they have difficulty understanding the steps of learning descriptive text using the TTW (think talk write) strategy.

Question no.9 shows that most of the students $(92,85 \%)$ say that learning descriptive text using the think talk write strategy is interesting, fun, and not boring. so that students can be more active in the learning process in class.

Question no.10 shows that most of the students $(64,28 \%)$ say that descriptive text learning by using the think talk write strategy can make the learning process in the classroom conducive. The others who is in the lowest quantity $(35,72 \%)$ say that feel less conducive when learning in class. Otherwise the students progress can be seen in the test that had been conducted.

From the data above, the students gave $81,78 \%$ positive responses to the think talk write strategy used during the learning process in class, most of the students have improvement in their learning of writing descriptive text. The students that have problem in construct generic structure and language feature, can improve their understanding better. Those, the students get many benifits in applying think talk write strategy in writing descriptive text. By using think talk write strategy, students can encourage to find out some new way in writing process especially in writing descriptive text and can improve their writing skill.

\section{CONCLUSION}

Based on the discussion above, the researcher conclude the students gave $80 \%$ positive responses to the think talk write strategy used during the learning process in class, it can be seen from the results of the questionnaire given to students. It can be conclude that learning by using think talk write strategy the students can encourage to find out some new way in writing process especially in writing descriptive text and can improve their writing skill. 


\section{ACKNOWLEDGMENTS}

Alhamdulillah, thanks to Allah S.W.T because the researchers can complete this article. The researcher also expressed his gratitude to the lecturer of all advices, so that the researcher can finish this article as best as possible.

\section{REFERENCES}

Kothari C. (2004). research methodology Methods and Techniques (second rev). New Age International Publishers.

Subkhan, M. A. L. I. (2016). The Implementation Of Think Talk Write ( Ttw ) In Teaching Writing To X Th Grade Students At Sman 1 Ngawen Blora Academic Year 2015-2016.

Suminar, R. P., \& Putri, G. (2018). The Effectiveness of TTW (Think-Talk-Write) Strategy in Teaching Writing Descriptive Text. Academic Journal Perspective: Education, Language, and Literature, 2(2), 300. https://doi.org/10.33603/perspective.v2i2.1666

Tambunan, Y. F. (2011). Improving The Students' Achievement in Writing Descriptive paragraphs by applying Think Talk Write Strategy. 1-12.

Wiyak, W., \& Ansori, I. S. (2017). Think-Talk-Write (Ttw) As a Strategy To Improve Students' Ability in Teaching Writing Descriptive Text: a Case of the Tenth Grade Students of Man Demak. ETERNAL (English Teaching Journal), 4(1), 80-91. https://doi.org/10.26877/eternal.v4i1.1948

Zulkarnaini. (2011). Model Kooperatif Tipe Think Talk Write (TTW) Untuk Meningkatkan Kemampuan Menulis Karangan Deskripsi dan Berpikir Kritis. Jurnal.Upi.Edu, 2, 144153. 